\title{
THE DEBT AND INVESTMENT STATUS OF TAMILNADU FARMERS
}

\author{
VIDHYAVATHI. A, PADMA RANI. S \& SIVASANKARI. S
}

Department of Agricultural Economics, Tamil Nadu Agricultural University, Coimbatore, India

\begin{abstract}
More than 80 per cent of farmers in India fall in small or marginal farmers group who require financial resources on a regular basis for their farming activities. in Tamil Nadu more than 90 Per cent of the farmers are marginal and small farmers. Therefore, accessibility to financial resources at reasonable terms and conditions is crucial for the well-being of the households. The agrarian crisis that has rampaged through rural India for the past few years has been associated with a rising burden of indebtedness among the farmers. The present study aimed in addressing the change in borrowing pattern of Tamil Nadu farmers over the decade, For what purpose they borrow at what terms of loan etc and the repayment capacity of the farmers. All India Debt \& Investment Survey of $59^{\text {th }}$ and $70^{\text {th }}$ rounds of National Sample Survey Organization data was used for the study. The results showed that mostly farm households borrow to meet their household expenditure which is unproductive. The average interest rate has declined for both the sources of credit and more farmers borrow for a shorter tenure than earlier. average amount of debt is Rs. 1,30,824 /farm household
\end{abstract}

KEYWORDS: Farm Household, Debt, Investment, Outstanding \& Assets

Received: May 23, 2019; Accepted: Jun 13, 2019; Published: Jul 04, 2019; Paper Id.: IJASRAUG201929

\section{INTRODUCTION}

"Indian agriculture is in a way, a victim of its own past success" particularly denotes the impact of green revolution. It is well known that around 80 per cent of farmers in India fall in small or marginal farmers group who require financial resources on a regular basis for their farming activities. Needless to say, as these households do not possess adequate savings, accessibility to financial resources at reasonable terms and conditions from financial intermediaries becomes a crucial parameter for their productive activities and hence, in turn, their well-being. The income levels of farmer households of developing countries like India are heavily influenced by uncertain climatic and market conditions and consequently they suffer from irregular and volatile earnings. Most of these households being from small and marginal farmers, they do not possess adequate savings and consequently depend on credit to meet even their basic expenses. Therefore, accessibility to financial resources at reasonable terms and conditions is crucial for the well-being of the households. Nearly 42per cent of the Indian people derive their income from farming (Economic Survey 2015-16). Nowadays the problem of farmers' suicides is one of the vital concerns that need to be addressed by the Government. Over 2,90,323 farmer's suicides during 1995-2014 and this account $13.9 \%$ of total suicide cases. Indebtedness is the major cause for farmer's suicides, accounting for $20.6 \%$. (NCRB Report - 2015) The agrarian crisis that has rampaged through rural India for the past few years has been associated with a rising burden of indebtedness among the farmers. The inability to repay the past debt therefore access to fresh loans has been widely accepted as the most significant proximate cause for the farmers' suicides. Here in our study, we are to discuss the change in borrowing pattern of Tamil Nadu farmers over the decade, for what purpose they borrow at what terms of loan etc... Next the repayment capacity of the farmers based on their 
farm size is calculated

Finally what are the major factors influencing debt among the farmers is found and the results are discussed

Indian Farm households who availed credit had increased from 48.6 per cent in 2003 to 51.9 per cent in 2013.

Outstanding loan percent of farm households from Institutional agencies has increased between 2002-03 and 2012-13. But still nearly $40 \%$ loans are from Non-Institutional agencies. Increasingly loans are taken for meeting household expenses. The major indicators of debt and investment of farm households are Incidence of Indebtedness is 45.94 per cent; Average amount of debt is Rs. 70,580 and Average Asset Value Rs. 2, 72,956. (Source: NABARD Rural Pulse, Issue - VIII, March - April 2015). With this back round the present research aims to assess the debt and investment status of farmers in Tamil Nadu with the following specific objectives

\section{OBJECTIVES}

- To study the borrowing pattern of Tamil Nadu farmers

- To assess the repayment of farms across size of holdings

- To identify the determinants of debt of farm households

\section{METHODS}

The National Sample Survey Organization (NSSO), Ministry of Statistics and Programme Implementation (MOSPI), Government of India has been conducting All-India Survey on Debt and Investment, decennially, since its 26th round (1971-72) in both rural and urban areas. These surveys generate basic information on assets, liabilities and capital expenditure in the household sector of the economy. The All-India Debt and Investment Survey (AIDIS), which was carried out as part of the $59^{\text {th }}$ round of the National Sample Survey (NSS) during January to December 2003, was the sixth such survey conducted at the all-India level. In its $70^{\text {th }}$ round of survey, conducted during the period $1^{\text {st }}$ January 2013 to $31^{\text {st }}$ December 2013, NSSO carried out a Situation Assessment Survey of Agricultural Households. These data by NSSO was extracted using the SPSS package Version 21. Which gives the estimates of indebted households and the amount of debt classified by various aspects for Tamil Nadu State. The survey provides the details of household liabilities required for the formulation of credit policy of financial institutions and planning for development.

\section{CONCEPTS AND DEFINITIONS}

\section{Reference Period}

Information is collected primarily for the agricultural year 2012-13 in two visits, viz., visit-1 and visit-2. For other items of information, different reference periods are used, viz., 'as on the date of survey' for land possession and outstanding loans, 'last 30 days' for farming of animals, non-farm business and consumer expenditure and 'last 365 days' for principal source of income

\section{Household Size}

The size of a household is defined as the total number of persons normally residing together (i.e., under the same roof) and taking food from the same kitchen (including temporary stay away and excluding temporary visitors) 


\section{Agricultural Household}

For the purpose of Situation Assessment Survey (SAS) of NSS 70th round, an agricultural household is defined as a household receiving some value of produce from agriculture activities (e.g., cultivation of field crops, horticultural crops, fodder crops, plantation, animal husbandry, poultry, fishery, piggery, bee-keeping, vermiculture, sericulture, etc.,) during last 365 days. However, household which are entirely agricultural labor household are excluded from the coverage. In contrast to the definition of farmer used in $59^{\text {th }}$ Round of NSS survey, the necessary condition of 'land possession' had been dispensed with in this round. In this connection, it is also important to note that apart from agricultural laborers, households receiving income entirely from coastal fishing, activity of rural artisans and agricultural services are not considered as agricultural household and they are kept out of the scope of the survey

\section{Farm Size}

The farmers surveyed are classified based on their farm size as Small, Medium and Large. Small farmers land holding $\leq 2$ ha, Medium farmers 2-5 ha and large farmers $>5$ ha

\section{Credit Agency}

The agency from which a loan was taken treated as the credit agency. The credit agencies were either 'institutional agencies' or 'non-institutional agencies'. The various agencies which were treated as 'institutional agencies' were: government, co-operative agencies, commercial banks including regional rural banks, insurance, provident fund, financial Corporation/institution, financial company and 'other institutional agencies'. The agencies which were treated as 'non-institutional agencies' were: landlord, agriculturist money lender, professional money lender, trader, relatives and friends, doctors, lawyers and other professionals, and 'others'

\section{Household Assets}

Assets include both Physical and Financial Assets. Physical assets include land, buildings, livestock, agricultural machinery and implements, non-farm business equipment, all transport equipment. Financial assets include dues on loans advanced in cash or in kind, shares in companies and cooperative societies, banks deposits in companies, banks, post offices

\section{Functional Analysis}

The secondary data of NSSO AIDIS $59^{\text {th }}$ and $70^{\text {th }}$ Rounds are collected and data extraction is done using SPSS software. For comparative study of the two survey Rounds $\left(59^{\text {th }} \& 70^{\text {th }}\right)$ average and percentage analysis tools are used. To identify the factors influencing debt of farm households multiple regression analysis is carried out

The general form of the function is

$\mathrm{Y}=\mathrm{b}_{0}+\mathrm{b}_{1} \mathrm{X}_{1}+\mathrm{b}_{2} \mathrm{X}_{2}+\mathrm{b}_{3} \mathrm{X}_{3+} \mathrm{b}_{4} \mathrm{X}_{4}+\mathrm{b}_{5} \mathrm{X}_{5}+\mathrm{b}_{6} \mathrm{X}_{6}$

Where, $Y=$ Debt of the households

$$
\begin{aligned}
& \mathrm{b}_{0}=\text { constant term } \\
& \mathrm{X}_{1}=\text { Age of the household (in years) } \\
& \mathrm{X}_{2}=\text { Education (in years) }
\end{aligned}
$$




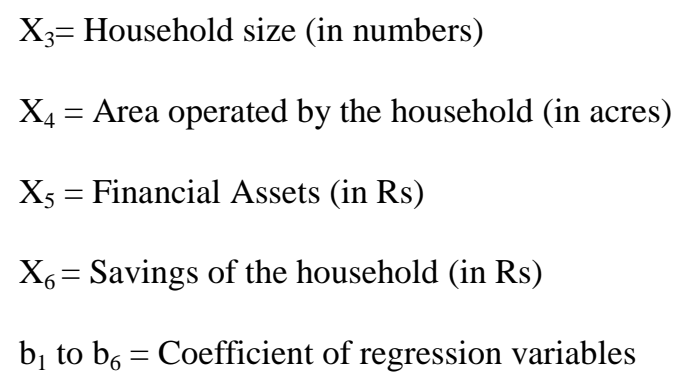

\section{RESULTS}

\section{Farm Size}

The farmers surveyed are classified based on their farm size as Small, Medium and Large. Small farmers land holding $\leq 2$ ha, Medium farmers 2-5 ha and large farmers $>5$ ha. The average farm size for each class is calculated for both rounds $\left(59^{\text {th }} \& 70^{\text {th }}\right.$ Rounds) and the results are tabulated below in Table 1 . The farm size has increased over the years in all the categories of farm size class

Table 1: Farm Size Classification

\begin{tabular}{|l|c|c|}
\hline \multirow{2}{*}{ Farm Size Class } & \multicolumn{2}{|c|}{ Farm Size (ha) } \\
\cline { 2 - 3 } & $\mathbf{2 0 0 3}$ & $\mathbf{2 0 1 3}$ \\
\hline Small & 0.36 & 0.68 \\
\hline Medium & 2.83 & 3.46 \\
\hline Large & 6.89 & 8.45 \\
\hline
\end{tabular}

\section{Household Size}

The size of a household is defined as the total number of persons normally residing together (i.e., under the same roof) and taking food from the same kitchen as defined by NSSO. Household size is classified across the farm size for the surveys conducted in 2002-03 and 2012-13. The average members of the households in each farm size class are given in Table 2. The number of households has increased in case of Small farmers and reduced in case of Medium and Large farmers

\section{Table 2: Household Size}

\begin{tabular}{|l|c|c|}
\hline \multirow{2}{*}{ Farm Size } & \multicolumn{2}{|c|}{ Household Size (No.s) } \\
\cline { 2 - 3 } & $\mathbf{2 0 0 3}$ & $\mathbf{2 0 1 3}$ \\
\hline Small & 4 & 5 \\
\hline Medium & 6 & 4 \\
\hline Large & 6 & 5 \\
\hline
\end{tabular}

\section{Agricultural Households in Debt}

Providing farmers' access to institutional credit has been the main rural policy goal as usury has been the major issue leading to serious and perpetual indebtedness of farmers. Due to input-intensive Green Revolution which monetized the rural economy and increase in consumption, the credit needs of farmers increased manifold. This situation necessitated multi-agency approach to meet the challenge of meeting the credit needs through formal agencies. As per the latest survey results, in 2013, about 55.51 per cent of the Tamil Nadu agricultural households (HH) were indebted from one agency or the other (Table 3.). Compared to this, in 2003, the proportion of HH who availed credit was 52.58 per cent. Thus, there was a disappointingly narrow decrease in the proportion of $\mathrm{HH}$ who could not obtain any loan during a period (between the years 2003 and 2013) which has seen maximum policy and institutional interventions such as doubling the credit 
programme, loan waivers, Banking Correspondents and Banking Facilitators, Financial Literacy and Inclusion drive, recapitalization of cooperatives and Regional Rural Banks and so on. One more trend in the data, again disquieting, is that increment in the proportion of borrowing households increased as one moves from small holdings to large holdings

Table 3: Percentage of Farm Households in Debt

\begin{tabular}{|c|c|c|c|c|c|c|}
\hline \multirow{2}{*}{$\begin{array}{c}\text { Farm } \\
\text { Size }\end{array}$} & \multicolumn{4}{|c|}{$\mathbf{2 0 0 3}$} & \multicolumn{3}{|c|}{$\mathbf{2 0 1 3}$} \\
\cline { 2 - 7 } & $\begin{array}{c}\text { Farmers } \\
\text { Surveyed }\end{array}$ & $\begin{array}{c}\text { Farmers in } \\
\text { Debt }\end{array}$ & $\begin{array}{c}\text { \% of Farmers } \\
\text { in Debt }\end{array}$ & $\begin{array}{c}\text { Farmers } \\
\text { Surveyed }\end{array}$ & $\begin{array}{c}\text { Farmers in } \\
\text { Debt }\end{array}$ & $\begin{array}{c}\text { \% of Farmers } \\
\text { in Debt }\end{array}$ \\
\hline Small & $\begin{array}{c}211 \\
(91.00)\end{array}$ & $\begin{array}{c}110 \\
(90.16)\end{array}$ & 53.08 & $\begin{array}{c}205 \\
(88.36)\end{array}$ & $\begin{array}{c}118 \\
(83.69)\end{array}$ & 53.39 \\
\hline Medium & $\begin{array}{c}18 \\
(7.70)\end{array}$ & $\begin{array}{c}10 \\
(8.20)\end{array}$ & 55.55 & $\begin{array}{c}19 \\
(8.62)\end{array}$ & $\begin{array}{c}18 \\
(12.76)\end{array}$ & 69.23 \\
\hline Large & $\begin{array}{c}3 \\
(1.30)\end{array}$ & $\begin{array}{c}2 \\
(1.64)\end{array}$ & 66.66 & $\begin{array}{c}7 \\
(2.72)\end{array}$ & $\begin{array}{c}5 \\
(3.55)\end{array}$ & 71.40 \\
\hline Total & $\begin{array}{c}232 \\
(100)\end{array}$ & $\begin{array}{c}122 \\
(100)\end{array}$ & $\mathbf{5 2 . 5 8}$ & $\begin{array}{c}232 \\
(100)\end{array}$ & $\begin{array}{c}141 \\
(100)\end{array}$ & $\mathbf{5 5 . 5 1}$ \\
\hline
\end{tabular}

(Figures in parentheses indicate per cent to total)

\section{Break-Up of Institutional and Non-Institutional Sources of Credit of Farm Households}

Successive All India Debt Investment Surveys showed that the proportion of institutional agencies in the total cash debts of cultivators has increased over time thus reflecting the success of rural credit institutionalization policy. Sources of credit availed by the farm households of Tamil Nadu is presented in Table 4. The contribution of Institutional agencies and Non-Institutional agencies are 58.78 per cent and 41.21per cent respectively in 2002-03. From the recent survey results it is found that institutional agencies share is about $61.59 \%$ and Non-Institutional agencies contribute $38.41 \%$. The share of Institutional agencies has been increased and the share of Non-Institutional agencies has been reduced. But still Non-Institutional agencies contribute nearly $40 \%$ of the credit source. Among the institutional agencies, the share of Commercial Banks (29.17\%) is more following the Co-operative Societies in both the surveys. The share of Co-operatives has declined in 2012-13 when compared to the previous survey. The share of Banks and Government has increased over the years. Among the Non-Institutional sources Money Lenders contribution is more followed by the share of Friends/Relatives, Traders, Landlord

Table 4: Break-up of Source of Credit Availed by the Farm Households in Percentage

\begin{tabular}{|l|c|c|}
\hline \multicolumn{1}{|c|}{ Source of Credit } & $\mathbf{2 0 0 3}$ & $\mathbf{2 0 1 3}$ \\
\hline Institutional Agencies & $\mathbf{5 8 . 7 8}$ & $\mathbf{6 1 . 5 9}$ \\
\hline Government & 1.60 & 1.90 \\
\hline Co-operative society & 25.16 & 20.30 \\
\hline Banks & 29.17 & 38.70 \\
\hline Other institutional sources & 2.85 & 0.69 \\
\hline Non-Institutional Agencies & $\mathbf{4 1 . 2 1}$ & $\mathbf{3 8 . 4 1}$ \\
\hline Landlord & 1.70 & 0.63 \\
\hline Money Lenders & 27.80 & 29.88 \\
\hline Shopkeeper/Trader & 2.90 & 0.20 \\
\hline Relatives/Friends & 4.70 & 3.80 \\
\hline Other Non-Institutional Agencies & 4.11 & 3.90 \\
\hline
\end{tabular}

\section{Agency - Wise Loan Amount Borrowed Per Household}

The average amount borrowed per household from Institutional sources has increased over the years, whereas the amount borrowed from Non-Institutional sources has declined. It is evidenced from Table 5 that though the informal 
sources contributed nearly 40 per cent of the total credit the amount borrowed from Non-Institutional sources was comparatively very less

Table 5: Amount Borrowed per Household - Agency Wise

\begin{tabular}{|c|c|c|c|c|}
\hline Farm Size & \multicolumn{4}{|c|}{ Amount borrowed by the Farm Households (Rs/Household) } \\
\hline & \multicolumn{3}{|c|}{2003} & \multicolumn{2}{c|}{$\mathbf{2 0 1 3}$} \\
\hline \multirow{2}{*}{ Small } & Institutional & Non-Institutional & Institutional & Non-Institutional \\
& 46,613 & 18,063 & 72,896 & 31,362 \\
& $(72.00)$ & $(28.00)$ & $(70.00)$ & $(30.00)$ \\
\hline \multirow{2}{*}{ Medium } & 43,222 & 10,000 & $1,06,429$ & 75,000 \\
& $(81.22)$ & $(18.78)$ & $(58.66)$ & $(41.34)$ \\
\hline \multirow{2}{*}{ Large } & 25,000 & 75,000 & $2,52,500$ & 15,000 \\
& $(25.00)$ & $(75.00)$ & $(94.39)$ & $(5.61)$ \\
\hline \multirow{2}{*}{ Average } & 31,611 & 44,354 & $1,43,941$ & 40,454 \\
& $(41.61)$ & $(58.39)$ & $(78.06)$ & $(21.94)$ \\
\hline
\end{tabular}

(Figures in parenthesis indicate per cent to total of farm class)

\section{Loan Amount Outstanding Based On Purpose}

Loans have been taken for different purposes such as meeting capital and current expenses for farm as well as non-farm business, household expenses on education, medical treatment, consumption, weddings, housing and other items. Distribution of loan outstanding according to purpose is given in Table 6. This reveals that the share of loans taken for farm business has come down while non-farm business has accounted for a higher share in 2013 compared to 2003. Increasingly loans are taken for meeting household expenses of which share of loans for medical purposes doubled and for education trebled. The share of other expenses has increased significantly over the decade. This has implications for the households and the financing agencies. Since formal agencies cannot fund household expenses, farmers have to take recourse to informal agencies. Formal agencies hardly have products for meeting household expenses except a few items such as higher education and housing. This trend may explain why the share of non-institutional agencies has not come down between 2003 and 2013

Table 6: Per Cent Distribution of Outstanding Loan Based on Purpose

\begin{tabular}{|c|c|c|}
\hline \multirow{2}{*}{ Purpose of Loan } & \multicolumn{2}{|c|}{ Distribution of Outstanding Loan (\%) } \\
\hline & 2003 & 2013 \\
\hline Farm Business & 58 & 32 \\
\hline Non-Farm Business & 7 & 13 \\
\hline Household Expenditure & 31 & 49 \\
\hline Others & 4 & 7 \\
\hline
\end{tabular}

\section{Distribution of Loans Outstanding based on Interest Rate}

There was a general decline in interest rates with a decline of average rate. The distribution of loan outstanding loan based on interest rate is furnished in Table 7. The decline in case of institutional loans was from 13.25 per cent in 2003. Interest rate on non-institutional loans declined from 18.25 per cent in 2003 
Table 7: Per Cent Distribution of Outstanding Loan Based on Interest Rate

\begin{tabular}{|c|c|c|c|c|}
\hline $\begin{array}{c}\text { Interest Rate } \\
\text { Class (5) }\end{array}$ & \multicolumn{4}{|c|}{ Distribution of Outstanding Loan (\%) } \\
\hline & \multicolumn{2}{|c|}{ Institutional } & Non - Institutional \\
\hline & $\mathbf{2 0 0 3}$ & $\mathbf{2 0 1 3}$ & $\mathbf{2 0 0 3}$ & $\mathbf{2 0 1 3}$ \\
\hline Nil & 3 & 1.5 & 16 & 16.2 \\
\hline $\mathbf{1 - 1 0}$ & 4 & 36 & 2 & 3 \\
\hline $\mathbf{1 0 - 1 2}$ & 20 & 10 & 3 & 1 \\
\hline $\mathbf{1 2 - 1 5}$ & 40 & 38.5 & 1 & 3.8 \\
\hline $\mathbf{1 5 - 2 0}$ & 28 & 5.9 & 3 & 5.9 \\
\hline $\mathbf{2 0 - 2 5}$ & 2 & 3 & 30 & 30.5 \\
\hline $\mathbf{2 5 - 3 0}$ & 0 & 0.7 & 1 & 0.8 \\
\hline$>\mathbf{3 0}$ & 1 & 1 & 37 & 33 \\
\hline $\begin{array}{c}\text { Average Interest } \\
\text { Rate }\end{array}$ & $\mathbf{1 3 . 2 5}$ & $\mathbf{1 2 . 0 7}$ & $\mathbf{1 8 . 2 5}$ & $\mathbf{1 6 . 0 5}$ \\
\hline
\end{tabular}

Distribution of Loans Outstanding based on Duration

The duration of outstanding loans from institutional and non-institutional sources are listed in Table 8. Most of the loans borrowed are of short tenure in nature mostly less than one year

Table 8: Per Cent Distribution of Loans Outstanding Based on Duration

\begin{tabular}{|c|c|c|}
\hline \multirow{2}{*}{ Duration in Years } & \multicolumn{2}{|c|}{$\begin{array}{c}\text { Distribution of Loan } \\
\text { Outstanding (\%) }\end{array}$} \\
\hline & $\mathbf{2 0 0 3}$ & $\mathbf{2 0 1 3}$ \\
\hline$<\mathbf{1}$ & 34 & 47 \\
\hline $\mathbf{1 - 2}$ & 25 & 22 \\
\hline $\mathbf{2 - 3}$ & 14 & 13 \\
\hline $\mathbf{3 - 4}$ & 9 & 5 \\
\hline $\mathbf{4 - 5}$ & 7 & 6 \\
\hline $\mathbf{5 - 1 0}$ & 8 & 7 \\
\hline$>\mathbf{1 0}$ & 6 & 4 \\
\hline
\end{tabular}

Amount Borrowed, Repaid and Outstanding Per Household Based on Farm Size

The amount borrowed, repaid and outstanding per household between 2002-03 and 2012-13 are tabulated below in Table 9. The repaying capacity of farmers has increased from 2003 to 2013

Table 9: Amount Borrowed, Repaid and Outstanding Per Farm Household (Rs.)

\begin{tabular}{|l|c|c|c|c|c|c|}
\hline \multirow{2}{*}{ Farm Size } & \multicolumn{2}{|c|}{ Borrowed (Rs.) } & \multicolumn{2}{c|}{ Repaid (Rs.) } & \multicolumn{2}{c|}{ Outstanding (Rs.) } \\
\cline { 2 - 7 } Small & $\mathbf{2 0 0 3}$ & $\mathbf{2 0 1 3}$ & $\mathbf{2 0 0 3}$ & $\mathbf{2 0 1 3}$ & $\mathbf{2 0 0 3}$ & $\mathbf{2 0 1 3}$ \\
\hline Medium & 30,641 & 56,721 & $\begin{array}{r}1,500 \\
(4.89)\end{array}$ & $\begin{array}{c}4,620 \\
(8.14)\end{array}$ & 33,453 & 49,412 \\
\hline Large & 91,667 & $2,52,500$ & $\begin{array}{c}2,500 \\
(2.72)\end{array}$ & $\begin{array}{c}16,500 \\
(6.53)\end{array}$ & 87,500 & $2,35,000$ \\
\hline Total & $1,68,237$ & $4,08,596$ & $\begin{array}{c}6,300 \\
(3.74)\end{array}$ & $\begin{array}{c}23,676 \\
(5.79)\end{array}$ & $1,64,025$ & $3,92,471$ \\
\hline
\end{tabular}

(Figures in parenthesis indicate per cent to amount borrowed by each category)

The average amount of debt borrowed per household by farmers in Tamil Nadu had increased from Rs. 54,675 in 2002-03 to Rs. 1, 30,824 in 2012-13. Debt had increased for all category of farm size from 2002-03 to 2012-13 


\section{Distribution of KCC Holders}

The percent of KCC holders had increased from 40.3 per cent in 2002-03 to 52.6 per cent 2012-13 (Table 10.) and the proportion of card holders had increased in all categories of farm class

Table 10: Per Cent Distribution of KCC Holders

\begin{tabular}{|c|c|c|}
\hline Farm Size & \multicolumn{2}{|c|}{ KCC Holders (\%) } \\
\hline & $\mathbf{2 0 0 3}$ & $\mathbf{2 0 1 3}$ \\
\hline Small & 19.52 & 38.18 \\
\hline Medium & 42.46 & 54.83 \\
\hline Large & 58.92 & 64.96 \\
\hline Average & 40.30 & 52.60 \\
\hline
\end{tabular}

\section{Asset Value of Farm Households}

Physical assets include land, buildings, livestock, agricultural machinery and implements, non-farm business equipment, all transport equipment. Financial assets include dues on loans advanced in cash or in kind, shares in companies and cooperative societies, banks deposits in companies, banks, post offices. The asset value of Tamil Nadu farmers is tabulated below for the years 2002-03 and 2012-13 in Table 11. The asset value of all categories of farm class had increased over the years. The average asset value in 2012-13 was Rs. 1, 46,610

Table 11: Asset Value of Tamil Nadu Farmers

\begin{tabular}{|c|c|c|c|c|c|c|}
\hline Farm Size & \multicolumn{6}{|c|}{ Asset value (Rs / Household) } \\
\hline & \multicolumn{2}{|c|}{ Physical Assets } & \multicolumn{2}{|c|}{ Financial Assets } & \multicolumn{2}{c|}{ Total } \\
\hline & $\mathbf{2 0 0 3}$ & $\mathbf{2 0 1 3}$ & $\mathbf{2 0 0 3}$ & $\mathbf{2 0 1 3}$ & $\mathbf{2 0 0 3}$ & $\mathbf{2 0 1 3}$ \\
\hline Small & 28,234 & 45,960 & 3050 & 16,002 & 31,284 & 61,962 \\
\hline Medium & 49,380 & 82,016 & 10,540 & 38,354 & 59,920 & $1,20,370$ \\
\hline Large & $1,02,846$ & $1,89,260$ & 35,690 & 68,240 & $1,38,536$ & $2,57,500$ \\
\hline Average & $\mathbf{6 0 , 1 5 3}$ & $\mathbf{1 , 0 5 , 7 4 5}$ & $\mathbf{1 6 , 4 2 6}$ & $\mathbf{4 0 , 8 6 5}$ & $\mathbf{7 6 , 8 5 0}$ & $\mathbf{1 , 4 6 , 6 1 0}$ \\
\hline
\end{tabular}

\section{Debt - Asset Ratio}

Debt - Asset ratio for the state had increased from 2.41 in 2002-03 to 2.72 in 2012-13The ratio greater than one implied that with the given value of assets the farmers could not repay their debt

\section{Determinants of Debt}

The state has achieved from time to time very high levels of productivity from all crops but still the farmers are reeling under heavy debt. The factors affecting indebtedness are age of the household, education of the household, household size, area operated of the household, financial assets of the household and savings made by the household. Multiple regression analysis was performed and the results are presented in Table 12

Table 12: Determinants of Debt of Farm Households

\begin{tabular}{|c|l|c|}
\hline S. No & \multicolumn{1}{|c|}{ Variables } & Regression Coefficient \\
\hline 1 & Intercept & $\begin{array}{c}-67614.50 * * \\
(15384.26)\end{array}$ \\
\hline 2 & Age ( in years) & $\begin{array}{c}-797.897 * \\
(410.36)\end{array}$ \\
\hline 3 & Education & $\begin{array}{c}391.88 * * \\
(355.06)\end{array}$ \\
\hline \multirow{2}{*}{4} & Household Size ( No. of family members) & $\begin{array}{c}18978.56 * \\
(411.82)\end{array}$ \\
\hline
\end{tabular}




\begin{tabular}{|c|l|c|}
\hline \multicolumn{2}{|c|}{ Table 12: Contd., } \\
\hline 5 & Area operated (ha/household) & $\begin{array}{c}8377.82^{*} \\
(3969.68)\end{array}$ \\
\hline \multirow{2}{*}{6} & Financial Assets (Rs./Household) & $\begin{array}{c}0.02^{\mathrm{NS}} \\
(0.02)\end{array}$ \\
\hline 7 & Savings(Rs./Household) & $\begin{array}{c}-0.01^{\mathrm{NS}} \\
(0.05)\end{array}$ \\
\hline & $\mathrm{R}^{2}$ & 59.81 \\
\hline & $\mathrm{F}$ & 101.25 \\
\hline
\end{tabular}

The value of $\mathrm{R}^{2}$ was found to be 0.5981 indicating that 59.81 per cent of the variation in the indebtedness was explained by the independent variables included in the equation. The regression coefficients of age, education, farm size, household size and area operated were significantly positive. This reveals that with an increase in these variables, the debt amount increases. However, the regression coefficient of financial assets and savings was not significant which indicates that their assets and savings were not sufficient to influence the amount of debt of farmers

\section{CONCLUSIONS}

As per the latest survey results, in 2013, about 55.51 per cent of the Tamil Nadu agricultural households (HH) were indebted from one agency or the other. The contribution of Institutional agencies and Non-Institutional agencies are 58.78 per cent and 41.21per cent respectively in 2002-03. From the recent survey results it is found that institutional agencies share is about 61.59 per cent and Non-Institutional agencies contribute 38.41 percent by the share of Friends/Relatives, Traders, Landlord. Though the informal sources contributed nearly 40 per cent of the total credit the amount borrowed from Non-Institutional sources was comparatively very less. Increasingly loans are taken for meeting household expenses of which share of loans for medical purposes doubled and for education trebled. The share of other expenses has increased significantly over the decade. The average amount of debt borrowed per household by farmers in Tamil Nadu had increased from Rs. 54,675 in 2002-03 to Rs. 1, 30,824 in 2012-13. Debt had increased for all category of farm size from 2002-03 to 2012-13. Debt - Asset ratio for the state had increased from 2.41 in 2002-03 to 2.72 in 2012-13. The ratio greater than one implied that with the given value of assets the farmers could not repay their debt. In case of factors influencing farm household debt, the regression coefficients of age, education, farm size, household size and area operated were significantly positive indicating that with an increase in these variables, the debt amount will increase Ratio of Agricultural Credit to Agricultural GDP increased from 10 per cent (1999-2000) to 38 per cent (2012-13) (Economic Survey 2015-16). Crop loans being short term in nature are meant to meet only the current expenditure for raising crops and do not result in any major investments in agriculture. Only if farmers can overcome the short-term contingencies and price shocks they can survive timely availability and access to credit both short term and long term credit from formal sources at affordable interest rate is essential to improve agricultural productivity. This improvement in crop productivity will solve farmer's woes, which cannot take place without better remuneration. This better remuneration can be attained only when efforts are taken to bridge the gap between ever increasing cost of farm inputs and lower cost of inputs. Loan waivers are not the solution; reasons for chronic indebtedness should be addressed. Mere prevention without any preventive measures for future would not help the situation 


\section{REFERENCES}

1. Economic Survey 2015-16.Https://Www.Indiabudget.Gov.In/...Economic_Survey2015/Pdf/Economic-Survey.Pdf

2. Rural Pulse, Issue - Viii, (March - April 2015).

Nabardhttps://Www.Nabard.Org/Demo/Auth/Writereaddata/Tender/1409165417ruralpulse\%20xiv.Pdf

3. Alapati, P. And Shaik, K.S., Improving Farmer's Knowledge On Indigenous Practice Of Spraying Pesticides In Grape Garden.

4. Darwis, I. Extension About The Groundwater Conservation And Its Influence On Farmers Knowledge And Attitude In Takalar Regency, Indonesia.

5. Kankarne, Y. O. G. E. S. H. W. A. R., Siddiqui, F. A. H. E. E. M., \& Kochewad, S. A. N. J. I. V. K. U. M. A. R. (2017). Effect Of Socio-Economic Traits On The Level Of Knowledge Of Dairy Farmers. International Journal Of Agricultural Science And Research, 7(1), 287-292. 